\title{
Eco-geomorphological connectivity and coupling interactions at hillslope scale in drylands: Concepts and critical examples
}

\author{
A. Calvo-Cases ${ }^{\text {a, }}$, E. Arnau-Rosalén ${ }^{\text {b }}$, C. Boix-Fayos ${ }^{c}$, J. Estrany ${ }^{\text {d,e }}$, M.J. Roxo ${ }^{\text {f }}$, E. Symeonakis ${ }^{\text {b }}$ \\ ${ }^{\text {a }}$ Inter-University Institute for Local Development (IIDL), Department of Geography, University of Valencia, Spain \\ ${ }^{\mathrm{b}}$ Department of Natural Sciences, Manchester Metropolitan University, UK \\ ${ }^{\text {c }}$ Soil and Water Conservation Group, CEBAS-CSIC, National Research Council, Murcia, Spain \\ ${ }^{\mathrm{d}}$ Mediterranean Ecogeomorphological and Hydrological Connectivity Research Team, Department of Geography, University of the Balearic Islands, Spain \\ ${ }^{\mathrm{e}}$ Institute of Agro-Environmental and Water Economy Research -INAGEA, University of the Balearic Islands, Balearic Islands, Spain \\ ${ }^{\mathrm{f}}$ Interdisciplinary Centre of Social Sciences (CICS NOVA), Faculty of Social Sciences and Humanities, FCSH, New University of Lisbon, Portugal
}

\section{A R T I C L E I N F O}

\section{Keywords:}

Runoff connectivity

Process-pattern

Hillslope-channel coupling

Soil surface armouring

Feedback

Scale

\begin{abstract}
A B S T R A C T
The diagnosis of land degradation requires a deep understanding of ecosystem functioning and evolution. In dryland systems, in particular, research efforts must address the redistribution of scarce resources for vegetation, in a context of high spatial heterogeneity and non-linear response. This fact explains the prevalence of ecohydrological perspectives interested in runoff processes and, the more recent, focused on connectivity as an indicator of system resource optimisation. From a geomorphological perspective and reviewing the concepts of eco-hydro-geomorphological interactions operating in ecosystems, this paper explores the effects of erosion on vegetation configuration through two case studies at different spatio-temporal scales. We focus on the structurefunction linkage, specifically on how morphological traits relate with different stages in the erosional sequence, both in the abiotic and the biotic domain. Results suggest that vegetation dynamics are affected by structural boundary conditions at both scales, i.e. by surface armouring related with rock fragments at the patch scale, and by the degree of hillslope-channel coupling at the hillslope scale. Our preliminary results can serve as new working hypotheses about the structure-function interplay on hillslopes. All this, taking advantage of the recent technological achievements for acquiring very high-resolution geospatial data that offer new analytical possibilities in a range of scales.
\end{abstract}

\section{Introduction}

Understanding the functioning and evolution of natural systems is a basic research endeavour, and a necessity for meaningful land degradation assessments (Brandt and Thornes, 1996; Geeson et al., 2001), particularly in the context of climate change where trajectories of ecosystem response are highly uncertain (Maestre et al., 2016). Research needs to deal both with the structural system complexity and with its non-linear response (Wainwright et al., 2011) which is governed by thresholds (Cammeraat, 2004). Particularly so in the drylands, where this complexity is exacerbated by the high spatial heterogeneity (Puigdefabregas et al., 1998; Lavee et al., 1998; Aguiar and Sala, 1999; Puigdefábregas, 2005) and the timing of trigger-events (Schwinning and Sala, 2004), respectively. In the context of water-limited ecosystems, resource redistribution is critical for plant growth and survival and the role of biotic-abiotic interdependence is in the origin of the operating principle of the source-sink dynamics.

Over the last decades, research on dryland ecosystem functioning has thus been dominated by the eco-hydrological perspective, which focuses on the water balance between vegetation and the inter-canopy bare ground (Rodríguez-Iturbe and Porporato, 2004). The role of runoff distribution has commonly been the research focus until the issue of connectivity became a primary challenge (Mayor et al., 2008, 2019; Okin et al., 2015; Saco et al., 2020).

Our aim here is to contribute to this eco-hydrological perspective from the geomorphological viewpoint, delving into the role of erosion processes in the vegetation configuration that affect hillslope connectivity. Specifically, by setting the current conceptual foundations in ecohydro-geomorphological system operation and presenting preliminary results from two case studies from different spatio-temporal scales in

\footnotetext{
* Corresponding author.

E-mail address: adolfo.calvo@uv.es (A. Calvo-Cases).
} 
process operation (namely, the patch and the hillslope/valley scales), we extract two new working hypotheses about the structure-function interplay at the hillslope for future empirical-based research.

\subsection{Conceptual basis of dryland functioning: from patch heterogeneity to the hillslope connectivity}

In water-limited ecosystems, the mechanisms that guarantee vegetation survival are strengthened at the patch scale, where spatial heterogeneity in the soil properties and their corresponding erosional response begins. Puigdefábregas (2005) developed the concept of Vegetation Driving Spatial Heterogeneity (VDSH), which synthesises the process of patch differentiation with contrasted properties through feedback mechanisms promoted by the vegetation. These mechanisms are the result of water and solar radiation, organic carbon, nutrient and sediment balances.

Contrary to bare areas, patches of vegetation function as resource traps (i.e. water, sediment and nutrients) thanks to their favourable conditions enhancing infiltration and preventing soil erosion, namely: (i) soil aggregation and porosity, promoted by the organic matter supplied by plants and the presence of macro-porosity related to the root system; (ii) the absence of surface sealing as the soil is protected from the impact of raindrops, and (iii) the slowdown of the flows by the development of plant mounds.

Therefore, soil-vegetation interactions lead to a spatial mosaic of areas with optimal conditions for infiltration (i.e. vegetated areas) and areas where higher runoff rates are recorded (i.e. bare areas between vegetation). This phenomenon is known as source-sink dynamics, which constitutes the operating principle in drylands allowing the spatial redistribution of resources.

Connectivity, a concept originally termed continuity by Brunsden and Thornes (1979), materialises when the source-sink scheme extends in space and relates to the way the organisation of patches determines the redistribution of overland flow (Yair and Lavee, 1976, 1985; Lavee and Yair, 1990; Bergkamp, 1998; Puigdefabregas et al., 1998; Puigdefábregas, 2005). This fundamental interdependence of bare soil and vegetation can acquire multiple spatial configurations depending on water balance variables, resulting in different degrees of overland flow continuity. Connectivity has been linked to the system efficiency in long-term resource retention, and is closely related to system health in terms of its functioning and, therefore, to its potential state of degradation (Tongway and Hindley, 2004; Kéfi et al., 2007; Okin et al., 2015). Over the last decade, quantifying connectivity and the associated loss of system resources, has become a challenge.

Advances in these issues come mainly from two approaches: (i) in the development of implicit connectivity indices in which the flow routing is considered incorporating the topographical variable, as is the case of the Leakiness index (Ludwig et al., 2007), the Flowlength index (Mayor et al., 2008, 2019) or the Sediment Connectivity Index (Cavalli et al., 2013), and (ii) in the indirect assessment of general spatial continuity of bare areas through the morphological attributes of vegetation patterns, ranging from simple spatial metrics (Imeson and Prinsen, 2004; Boer and Puigdefábregas, 2005) to patch-size frequency distribution inferences (Kéfi et al., 2007; Scanlon et al., 2007; Maestre and Escudero, 2009).

A common feature, however, is the widespread usage of binary vegetation/non-vegetation maps in the analysis justified by the sharp contrasting response of its constituents. This fact is explained by the prevalence of the eco-hydrological perspective in the source-sink conceptualisation, simplifying at this stage the inter-canopy non-vegetated area as homogeneous net water supplier to vegetation.

Nevertheless, there is a growing field of research that emphasizes the role of the Biological Soil Crusts in dryland functioning (Belnap, 2006; Maestre et al., 2013), particularly in water, nutrient and sediment redistribution balances (Kidron and Yair, 1997; Chamizo et al., 2016), thus evidencing the relevance of the diversity in composition as a fundamental dimension of the analysis.

However, in addition to these efforts to broaden considerations from the biotic domain, the complexities added by abiotic factors to the system functioning also need to be considered. In particular, the foundations of the hydro-geomorphological operation of the hillslopes conceptualised from field empirical evidence, could help include the erosional processes involved in hillslope connectivity across-scales. Benchmark contributions established the factors involved in overland flow discontinuities along the hillslope, both spatially (Yair and Lavee, 1976, 1985; Lavee and Yair, 1990; Lavee et al., 1998) and temporally related with rainfall events (Puigdefabregas et al., 1998; Calvo-Cases et al., 2003; Cammeraat, 2004).

\subsection{The effect of erosion on vegetation structure: a contribution of geomorphology to the hillslope connectivity issue}

In the last decade, the conceptualisation of connectivity (Bracken and Croke, 2007; Bracken et al., 2013), the search for analytical frameworks from different perspectives (Lexartza-Artza and Wainwright, 2009; Bracken et al., 2015) and scale levels (García-Ruiz et al., 2010), have advanced significantly, especially in the field of geomorphology. In this context, there is an ongoing debate related with the functional and structural connectivity (Wainwright et al., 2011; Baartman et al., 2013).

In this regard of linking structural and functional dimensions, and particularly in the erosion/vegetation interplay, the effect of vegetation cover on the exponential reduction of soil erosion rates is well known, as it is one of the earliest identified and most extensively studied processes (Thornes, 1990; Abrahams et al., 1995; Gyssels et al., 2005). Later, interest turned to the effect of spatial configuration of vegetation on the redistribution of surface runoff (Cammeraat, 2004; Puigdefábregas, 2005; Ludwig et al., 2005; Bautista et al., 2007; Kéfi et al., 2007). However, despite these advances on how vegetation spatial patterns traits (i.e. the structural dimension) affect the operation of processes (i.e. the functional dimension), as Thornes (1985) had already pointed out, much less attention has been paid to the influence of erosion over vegetation dynamics.

The contribution of John B. Thornes in the two-way eco-geomorphological interactions was remarkable and was mainly achieved through the framework of the EU MEDALUS projects (Brandt and Thornes, 1996; Geeson et al., 2001). These projects are considered milestones for research on dryland land degradation processes, from which conceptual and methodological bases for improved understanding of such eco-geomorphological interplay were developed (i.e. Sanchez and Puigdefabregas, 1994; Kirkby et al., 1998; Puigdefabregas et al., 1999; Puigdefábregas, 2005). Regarding the issue of connectivity, in specific, Puigdefabregas et al. (1999) added the complexities of the vegetation and erosion interplay to the discourse through the water and sediment redistribution, emphasising the scale and the linkages between processes and patterns. The source-sink dynamics was conceived here as a game of tuning between the flow lengths and the development of the vegetation based on specific boundary conditions in each situation, which in turn is conditioning the connectivity of the fluxes along the hillslope.

\subsubsection{The role of soil surface armouring by rock fragments}

Most progress, in relation to how structure traits affect functioning, has been made at the patch scale, and more specifically, in how the high spatial variability of the observed responses in runoff and erosion is related to the coverage of the ground surface (Lavee et al., 1998). Therefore, in addition to the well-known effect of plants, the role of rock fragment position, cover and size (Lavee and Poesen, 1991; Poesen and Lavee, 1994; Poesen et al., 1994; Katra et al., 2008), the dynamics of surface sealing (De Ploey and Poesen, 1984; Roth, 2004) and the role of biological soil crusts (Alexander and Calvo, 1990; Kidron and Yair, 1997; Belnap et al., 2005) have also been considered relevant in 
modifying the hydrological response. Based on these findings, the concept of Soil Surface Components (SSC) emerged (Kutiel et al., 1998; Lavee et al., 2004) as the most elementary, visible, identifiable and discrete expression of such soil surface properties and, therefore, as homogeneous units of hydrological response (Arnau-Rosalén et al., 2008).

Regarding the two-way vegetation/erosion interaction, this was synthesised in the MEDALUS model by means of three feedback loops and their inter-relationships that govern the dynamics of system operation, i.e. organic, erosion and armour loops (Kirkby et al., 1996; 1998, in Fig. 1A). The relevance of these feedbacks is in settling the linkage between the structural variables (vegetation cover, soil depth, surface armouring, etc.) and the response variables (runoff and erosion rates) in a mechanistic way. Organic and erosion loops reproduce in the model direct and indirect effects between vegetation and erosion processes (Fig. 1). The direct effect is the well-known vegetation control of soil erosion at each rainfall event by protecting the soil surface through rainfall and runoff inception and avoiding soil particle detachment and transport. The indirect effects are related with soil water retention capacity and are both qualitative and quantitative: the state, dependent on soil condition, is altered qualitatively by organic matter content and affects infiltration and soil water retention capacity; and quantitatively by soil erosion affecting soil depth.

In addition, the MEDALUS model incorporates a third feedback, the surface armouring loop, which is related to the increase of rock fragments cover as the soil surface erodes over time. In this case, it has a direct effect on the runoff and erosive response (Fig. 1), but with the particularity of having a bimodal behaviour. This duality means that this loop is subjected to a threshold condition in relation to the stage of development of the surface armouring. This phenomenon is grounded from the empirical results reached on the runoff response to different cover and positions of rock fragments (Poesen and Lavee, 1994; Poesen et al., 1994).

In the model, there is a prevalence of positive feedback loops, with only a negative one when the armour loop switches to an inverse relationship with runoff/erosion rate. Positive feedbacks reinforce the system functioning towards a certain path or trajectory, both individually within each loop, and synergistically. Whereas the negative feedbacks, has a potential regulatory effect in the uni-directional trajectories that the system can reach. In other words, in the MEDALUS model, the armour loop can act as counterbalancing the reinforcing effect of the rest of the positive feedbacks.

When the model is interpreted at the patch-scale (i.e. a single vegetated or bare-soil patch, Fig. 1B), the reinforcing effect of vegetation and erosion positive loops has simultaneous opposite trajectories, with divergent results depending on whether it is a vegetated or a bare patch (as unfolded in Fig. 1B). Therefore, the result is a spatial differentiation or divergence in the soil properties with contrasting hydrologic responses, issue that Puigdefáfregas (2005) synthetized with the concept of Vegetation Driven Spatial Heterogeneity (VDSH): the precursor of the source-sink dynamic mechanism. Nevertheless, the scope of the potential regulatory role of the armour loop in the general system functioning remains understudied.

\subsubsection{Coupling and decoupling of the hillslope-channel system}

According to Harvey (2001, p. 226), "despite its importance in influencing how geomorphic systems respond to environmental change, there have been relatively few studies of the role and mechanisms of coupling within fluvial systems". This is especially pronounced in the coupling between hillslopes and river channels. In relation to channels, hillslopes can be not-coupled or absolutely disconnected, decoupled, or temporally disconnected by a barrier, and coupled, when there is a free transmission of mass and energy between both system parts (Harvey, 2001). From the fluvial point of view, the coupling-decoupling of the hillslope sediment cascades to the stream (Harvey, 2012) has been the focal point of interest for a variety of timescales (Caine and Swanson, 1989; Heckmann and Schwanghart, 2013; Del Vecchio et al., 2018; Michaelides et al., 2018).

Hillslopes coupled to the channel, after channel downcutting or bank erosion, are subject to effective erosion processes, such as rilling, gullying (Harvey and Calvo-Cases, 1991) or landslides (Savi et al., 2013). The coupling-decoupling interplay is very relevant in piping formation (Faulkner et al., 2008) and badlands development (Faulkner, 2008; Calvo-Cases et al., 2014), situations in which the hillslope strength resistance (i.e. lithology) is favouring a fast upslope spread of the waves of aggression. Where channel incision is lowering the hillslope's local base level (i.e. during the last millennia), the morphological resistance of the hillslopes changes as a consequence of the increase of the average slope, especially at the lower part (i.e. basal convexity). Often, morphological changes are not evident in the upslope part (i.e. rills or gullies). In these conditions, it can be assumed that the propagation of the changes is occurring "as diffuse waves of aggression away from the river channels or linear axes of change" (Brunsden and Thornes, 1979, p. 476). Thanks to the energy diffusion and storage (i.e. internal runoff discontinuities), the hillslope internal filters resistance (Brunsden, 2001) are not overpassed to reach an appreciable morphological change.

The strong strength resistance of hillslopes on some lithologies that need long timescales to show morphological changes (e.g. limestones) does not necessarily imply the absence of other changes in the mediumshort term. The diffuse waves of aggression are operating and affecting the soil-plant system via the changes in the transmission resistance (i.e. the vegetation size and distribution). This can be done by the influence of diffuse soil erosion over the other factors in the interactive loops (Fig. 1) that include affection over the soil water balance, as described by Loheide and Booth (2011) on hillslopes under the coupling effect.

\section{Example study cases}

In order to illustrate the role of interplant processes and the influence of coupling-decoupling conditions over hillslope structure, the following study cases were developed with adapted methodologies for two spatial scales: the inter-patch and the hillslope/valley scale. The first example analyses source-sink relationships mediated by the abiotic SSC
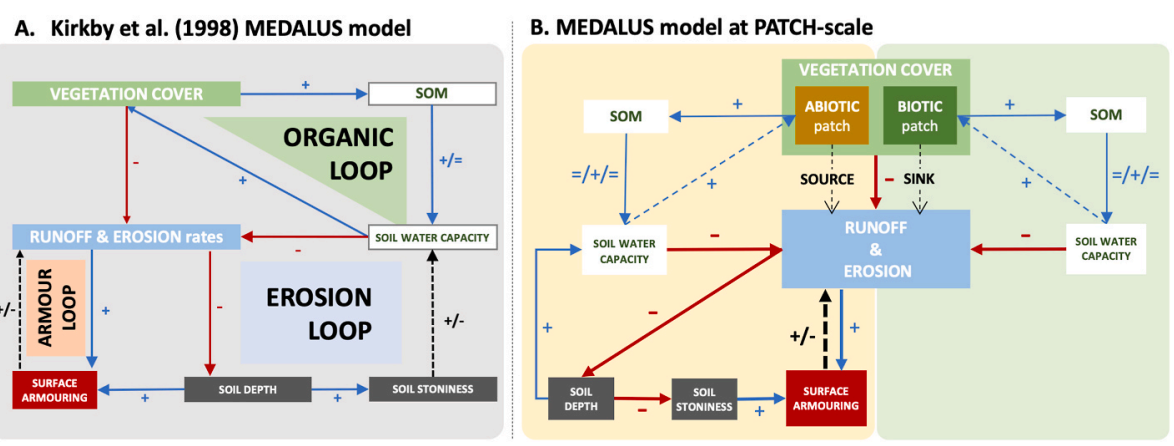

Fig. 1. (A) Organic, erosional and armouring feedback loops involved in the erosion-vegetation interplay based on the hillslope scale MEDALUS model (Kirkby et al., 1998). (B) MEDALUS model expressed at Patch-scale, differentiation between biotic and abiotic patches. Red and blue arrows correspond to positive and negative relationships. Black, dashed arrows depict relationships that can switch \pm sign depending on intrinsic thresholds associated with the value of a state variable. (For interpretation of the references to colour in this figure legend, the reader is referred to the Web version of this article.) 
composition in the source areas along a hillslope. The second analyses the source and sink sizes and distribution on the valley sides of three subcatchments of the same system but with different degrees of coupling hillslope/channel. In order to illustrate some of the relevant issues related to geomorphological activity in semi-arid environments. These examples have been selected as a nested-hierarchical approach; to illustrate some of the relevant issues related to geomorphological activity in semi-arid environments.

\subsection{Study area}

The two study cases are part of the Serra de la Cortina, a small mountain range with a SW-NE direction, reaching $524 \mathrm{~m}$. a.s.l. (Fig. 2) at $4 \mathrm{~km}$ from the Mediterranean coast of Benidorm (Alicante). The climate is dry (387 $\mathrm{mm}$ year ${ }^{-1}$ and $17.9{ }^{\circ} \mathrm{C}$ of annual mean temperature). Shallow $(<30 \mathrm{~cm})$ Lithic Leptosols and Petric Calcisols (Boix-Fayos et al., 1998; Boix-Fayos, 1999), over Upper Cretaceous (Senonian) limestones, have a high carbonates content (25-52\%) and very low organic matter ( $5.18 \%$ on the more vegetated north-facing slopes). The soil structure includes large and massive aggregates related to earthworm's activity (Boix-Fayos et al., 2001), although with high bulk density and low water retention capacity. Vegetation series are defined as Stipion tenacissima (Rivas-Martínez, 1987) dominated by Macrochloa tenacissima and disperse Pinus halepensis trees.

Past land uses, agriculture in terraces, grazing and esparto grass or alfa grass harvesting, were progressively abandoned between 1940 and 1975 (Boix-Fayos, 1999) and, since then, no human interference has directly affected the hillslopes. However, after 1995, intense urban development has taken place on the alluvial fans at the lower part affecting some of the valley bottoms (e.g. by means of gravel removal from some channels to infill other converted into streets).

Three small catchments $\left(0.4 \mathrm{~km}^{2}\right.$ in total $)$ draining the SE face of the mountain ranges have been selected (Fig. 2C) as examples of different degrees of coupling between hillslopes and channels. The selected catchments are not affected by the abovementioned recent changes, except for the sediment removal in channel 3, which suffered a significant emptying of 2-3 m, visible as a break in the longitudinal profile of Fig. 4B.

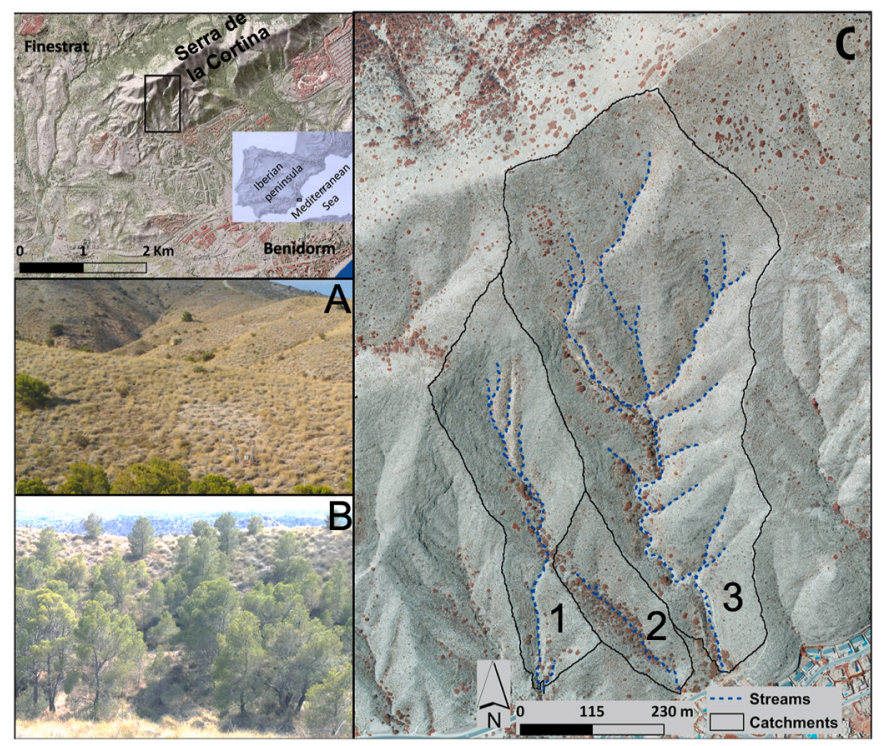

Fig. 2. Location map of the three studied catchments (C). A and B, frontal views of the SW and NE facing hillslopes, respectively, at catchment 2.

\subsection{Characteristics of the source areas along a hillslope}

The hillslope scale example has developed in both NE and SW facing valley sides of catchment 2 , where several previous experimental studies had been carried out (i.e. Boix-Fayos, 1999; Calvo-Cases et al., 2003; Arnau-Rosalén et al., 2008; Arnau-Rosalén, 2015).

\subsubsection{Methodology}

Colour RGB images taken from an unmanned aerial vehicle (UAV), were processed in Agisoft Metashape Pro 1.6 for Structure from Motion and Multi-View Stereo (SfM-MVS), obtaining a high resolution $(1 \mathrm{~cm})$ digital elevation model (HR-DEM) and orthophoto, referenced to previously established ground control points (Arnau-Rosalén, 2015) with a total station in a local coordinate system $($ RMSE $=0.0059 \mathrm{~m})$.

From the orthoimage, the plants and clumps were extracted by image classification and discretised into polygons. The areas draining to each plant were mapped using ArcMap 10.6 (Spatial Analyst, Hydrology, D8 algorithm) and applied to the HR-DEM after removing the areas covered by individual or clustered plants. The UAV orthoimage was classified into five classes (ArcMap 10.6, Iso Cluster Unsupervised Classification), which were then grouped into two: 'plants' and 'non-plants'. The pixels of the 'plants' class where replaced in the HR-DEM by hollows acting as sinks for the runoff.

In addition, a detailed mapping of the abiotic fraction of the SSC was digitised by photo-interpreting ground-obtained images with a $3 \mathrm{~mm}$ spatial resolution (Arnau-Rosalén, 2015), overlapped to the UAV imagery. Abiotic SSC classes were identified and mapped, based on their response to processes (Arnau-Rosalén et al., 2008): (i) rock fragments (RF) with three interval ranges (i.e. $<25 \%$; $25-75 \%$ and $>70 \%$ ) (ii) $R F$ position relative to surface (i.e. on-top and embedded); and (iii) rock outcrops. To further refine the analysis, the abiotic SSC were reclassified according to the stage of the surface armouring layer development, in three subsequent classes (i) well-developed surface armouring layer (i.e. $>25 \%$ RF on top): acting as soil protection with improved infiltration capacities corresponding (armouring-loop working as negative feedback, in Fig. 3); (ii) earlier armouring stage (including $<25 \% \mathrm{RF}$ on top and $<70 \% \mathrm{RF}$ embedded) acting as active erosional areas with enhanced erosional and runoff rates (armouring-loop working as positive feedback, in Fig. 3); (iii) exhaustion stage (i.e. rock outcrops and $>70 \% \mathrm{RF}$ embedded) corresponding to the absence of soil depth (armouring-loop already working irreversibly as positive feedback).

A. SINK/SOURCE Ratio

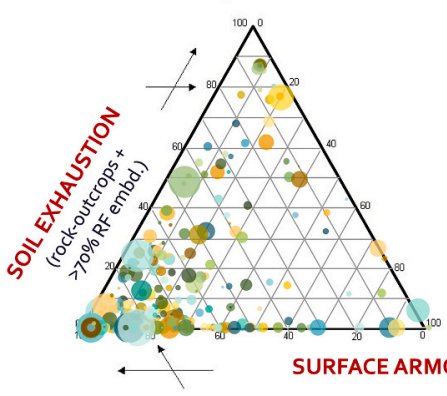

Fig. 3. Source-Sink Functional Composition triangles representing the compositional distribution of each source-sink binomial, according to ecogeomorphological processes. Soil Surface Components (SSCs) of the source fraction are classified in three abiotic functional categories corresponding to the axes: (i) exhaustion stage of soil depth acting as net runoff areas; (ii) welldeveloped stage of Surface Armouring, acting as soil protection, and (iii) bare soil representing the early stages of surface armouring, acting as current active erosional source areas. The compositional contribution of the biotic fraction is depicted as: (A) Sink/Source Ratio (SiSo-ratio), and (B) Plant or Clump Size. In (A), the size of the circles is relative to the magnitude of the ratio, while in (B), it is relative to the plant size. 


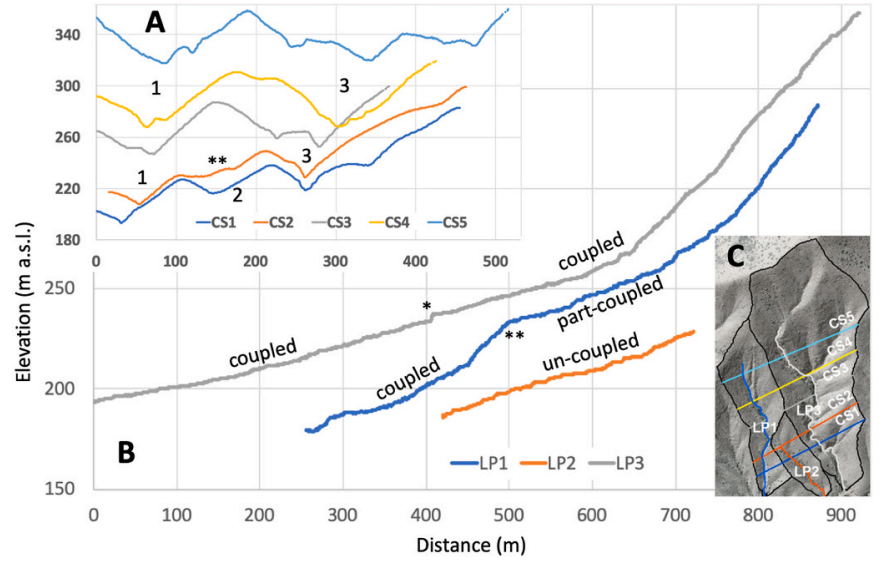

Fig. 4. (A) Cross-sections and (B) longitudinal stream profiles of the main channels that appear in the inset map (C) and Fig. 5A. The channel sediments were removed downstream of the single asterisk (*) in catchment 3 . The double asterisk $(* *)$ in (A) and (B) denote the point upstream from which, the area that used to drain into catchment 2 was captured by catchment 1 .

\subsubsection{Results}

The Source-Sink Functional Composition triangles in Fig. 3 provide evidence of a non-random distribution of the data, demonstrating preferential domains in the graphic pointing out to a variety of compositional combinations of abiotic-SSC with divergent vegetation fraction behaviour. Three main domains can be identified in the abiotic composition according to their relative abundance in plant settlement (i. e. data points scattering). The most frequent compositional mixture in source areas is that dominated by those abiotic SSCs indicative of surface armouring (hereon, ARM) in an advanced stage of development. The next compositional domain in plant settlement abundance, although much less present, is that dominated by abiotic SSCs indicative of soil exhaustion (hereon, EXH). The dominance of those abiotic SSCs indicative of early stages of armouring layer (hereon, ERO) is, practically, anecdotic, as there are very few plant settlements above $40 \%$ of ERO $\left(\mathrm{ERO}_{>40}\right)$.

The Sink/Source Ratio in Fig. 3A (hereon, SiSo-ratio), represents the spatial equity relationship between the sink and source patches. It is a measure of plant dependency to the runoff supply from its drainage area (source) according to its actual size. This means that, for example, the lower values of SiSo-ratio correspond to higher dependencies. The average value of SiSo-ratio is 0.61 (CV 283.20\%). The higher ratio values appear where armouring is dominant $\left(\mathrm{ARM}_{>70}\right)$, and in some cases, with high soil exhaustion or with absolute dominance of active erosive surfaces (Fig. 3A).

Despite the relevant implications of this ratio on the system functioning, it is dimensionless, and therefore, it is not informative of the effective potential development of the plants (i.e. actual plant growth), in the respective settlement domains in Fig. 3. From the simultaneous interpretation of both variables, SiSo-ratio and plant-size (i.e. the relative sizes of the circles in Fig. $3 \mathrm{~A}$ and $\mathrm{B}$, respectively), through the different compositional domains of the source areas (i.e. triangle sectors), different patterns can be identified in the abiotic-biotic interplay, with functional implications.

Firstly, the most favourable compositional domain for the development of vegetation growth is narrowed in the plant-size triangle compared with the SiSo-ratio one (Fig. 3B and A, respectively). More specifically, it is constrained to the domain of $\left[\mathrm{ARM}_{50-90}+\mathrm{ERO}_{>5-30}+\right.$ $\left.\mathrm{EXH}_{0-35}\right]$, which act as relatively narrow compositional boundary conditions to the development of vegetation in this hillslope. On the contrary, the rest of the compositional domains are to some extent limiting to plant growth, even in domains with higher SiSo-ratio, and consequently, having less dependence on their source areas. This is the case of $\left[\mathrm{ARM}_{90-100}+\mathrm{ERO}_{0-10}+\mathrm{EXH}_{0-10}\right]$ and more generally the $\left[\mathrm{ERO}_{0-10 \mathrm{aprox}}\right]$ and $\left[\mathrm{ARM}_{<50}\right]$.

These results show that, although the prevalence of ARM surfaces enhance plant growth, there is a need to diversify the source area with SSCs that have more runoff rates than ARM. This way, plant-size is constrained in circumstances of absolute dominance of ARM (i.e. in the case of this hillslope with a threshold of $\left[\mathrm{ARM}_{>90}\right]$, Fig. $3 \mathrm{~B}$ ), where water intake by runoff becomes the limiting factor for plant growth. In the other domains, where plant size is also restricted, despite having guaranteed runoff by the dominance of ERO and/or EXH, the limiting factor is the soil availability.

The general compositional distribution of the abiotic fraction according to three different erosional conditions shows that the hillslope has experienced high erosional rates in the past due to a relatively high presence of soil exhaustion conditions, specifically in the divide (Arnau-Rosalén, 2015). However, the fact that plants/clumps larger in size are narrowed into more restricted domains in the triangular graph of Fig. 3B, suggests that the armouring layer has been effective in conserving soil depth, even allowing the redeposition from the upper parts.

\subsection{Source and sink, size and distribution on coupled and decoupled hillslopes}

The three catchments in Fig. 2C are tributaries of the same system in different coupling hillslope-channel degrees, depending on the part of the catchment (Fig. 5A). This is a consequence of the changes in fluvial network patterns during Holocene re-establishment of the main channels after a general aggradation of the valleys, that links with the alluvial fan sequences forming a large pediment at the base of the Serra de la Cortina (Harvey, 1978). The capture between catchments 1 and 2, possibly by overflooding the divide, and sending the upstream area (pointed $* *$ in Fig. 4) to the stream 1, dates from previous times or from the beginning of the Holocene incision. Later, the incision was delayed by agriculture practices (e.g. check-dam terraces in some of the valley floors, Fig. 5A) in some of the remaining channel fills. The artificial sediment removal in the lower half of catchment 3 is relatively recent to be reflected on the hillslope's dynamics; this channel was already incised, and the removed sediments affect only to the channel gravels.

\subsubsection{Methodology}

In order to analyse the influence of the different coupling degree between hillslopes and channels on hillslope characteristics, we analysed topography and vegetation cover using a LiDAR-derived highresolution digital terrain model (HR-DTM) from 2016, and RGB + IR orthoimages of $25 \mathrm{~cm}$ spatial resolution from 2019 (both from www.icv.

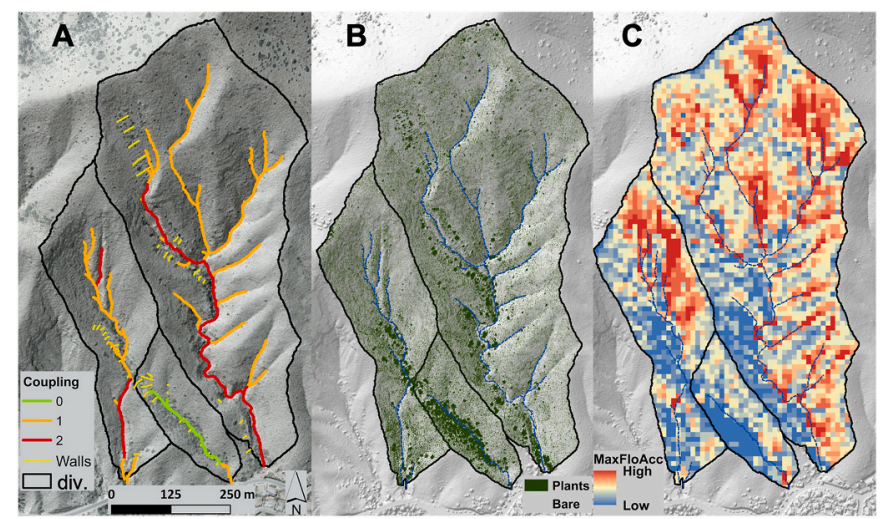

Fig. 5. (A) Estimated degree of coupling $(0,1,2)$ of the main channels and position of the remaining agricultural terrace-walls. (B) Plant patches obtained from the $0.25 \mathrm{~m}$-pixel orthoimage by RGBVI (see text). (C) Maximum drainage area of the bare patches flowing to the plant clumps summarized per 100 $\mathrm{m}^{2}$ squares. 
gva.es). The HR-DTM was derived from the pre-classified ground points of the 2016 LiDAR data (http://centrodedescargas.cnig.es), with an average points density of $0.5-4$ points $\mathrm{m}^{-2}$ and a RMSE $\mathrm{Z}$ of $0.2 \mathrm{~m}$, according to the data source (https://pnoa.ign.es/el-proyecto-pnoa-lidar). The LiDAR points where interpolated by the Inverse Distance Weighting (IDW) algorithm and nearest neighbour resampling to $1 \mathrm{~m}$ pixels with ArcGIS 10.6. The spatial distribution of vegetation was estimated using a vegetation index as a proxy for vegetation vigour, the Red Green Blue Vegetation Index (RGBVI; Bendig et al., 2015), at a $25 \mathrm{~cm}$ spatial resolution. The RGBVI discriminated well the different plants found in the area, dominated by Macroclhoa tenacissima, over a threshold value of 0.066 and was largely unaffected by the effect of plant shade. The resulting map (Fig. 5B) allowed for a quantitative, numerical analysis of the properties of bare and vegetated patches.

After removing the vegetation patches in a Digital Terrain Model (DTM), previously resampled to the same resolution as the Plants map (i. e. $25 \mathrm{~cm}$ ), flow accumulation (ArcMap, Hydrology, D8 algorithm) was calculated and applied to the analysis to calculate the bare patches' micro-catchment size. The statistical analysis was performed with InfoStat (Di Rienzo et al., 2020).

\subsubsection{Results}

Three channel-hillslope coupling situations were identified (Figs. 2C and 5A):

- Catchment 1 , with a very incised thalweg in the lower part, while at the middle part the incision appears much more recent (i.e. the incision is affecting old agricultural terraces). In one of the head-waters, a significant incision is cutting Pleistocene deposits in a deep trench with very coupled hillslopes (Fig. 5A).

- Catchment 2 has its valley bottom filled with sediments preserved by agricultural terraces and decoupled hillslopes. This valley lost its headwaters when it was captured by Catchment 1 .

- Catchment 3 is very incised all along the main channel, especially in the lower half, where a deep original incision is exacerbated by the abovementioned recent removal of gravel. Most of the dissection here seems to have occurred before that agricultural terraces that were built in the margins of the incision.

Actual plant cover and distribution demonstrate differences between the three catchments. On average, vegetation covers $28.3 \%$ of the area of the three basins. Per basin, these figures are $30.4 \%, 46.1 \%$ and $25.5 \%$, respectively (Table 1A). Those values highlight the influence of the coupling degree over the vegetation cover.

The average size of the mapped plant clusters with the RGBVI classification of the 2019 orthoimage (Fig. 5B), is very small: $75 \%$ of the plants are under $0.5 \mathrm{~m}^{2}$. Table 1 summarises plant size statistics, percentiles over the median and the mean, and shows plant size values according to the coupling degree. Regarding the influence of aspect on plant cluster size, Table 1 also summarises the measurements applied to contrasting valley sides in the lower half of the catchments. The differences introduced by the coupling degree in the plant size are much contrasted in the NE facing hillslopes than in the SW, both for medium plant size $\left(2.9 \mathrm{~m}^{2}\right)$ and for vegetation cover $(20.1 \%)$. Values are always higher in the decoupled hillslope. The differences between SW facing hillslopes are smaller, but also the decoupled hillslope have higher values, especially in terms of cover (11.1\%). Plant size variability is larger in the NE facing slopes and, amongst them, the uncoupled NE slope shows the highest variability. Within the SW facing slopes, the decoupled situation also demonstrates the largest coefficient of variation in plant size (Table 1B).

According to the source-sink dynamics, plant size is largely dependent on the runoff area draining to each plant. Fig. 5C shows the maximum catchment area draining to the plant clusters sampled within $100 \mathrm{~m}^{2}$ cells. The contrast introduced by aspect is clear in the figure, as are the differences between catchments, which links with the degree of coupling, as mapped in Fig. 5A.

Implications on processes are evidenced by the higher plant size range of their frequency distribution. Independently of the aspect, runoff continuity may be affected by the coupling degree of the hillslope to the channel. In this study area, the decoupled hillslopes with the same aspect have demonstrated significantly higher values of plant size and cover than the hillslopes coupled to the channel since the early Holocene incision phases. The size of the areas contributing to each plant has an inverse behaviour. At the less eroded and degraded soil of the decoupled hillslopes, the need for large runoff source areas decreases as soil availability increases under the plant's protection. In this previously highly degraded area, as a consequence of land abandonment, the recovery of plant size, vegetation cover and soil has been faster and better at the valley sides that remained decoupled to the main channel.

\section{Discussion}

The objective of the two examples presented here was to explore how different structural boundary conditions, related to soil erosion dynamics, affect vegetation development. The main aim was to continue deepening into the two-way vegetation-erosion relationship and, consequently, strengthen the eco-geomorphological perspectives to be included in the study of dryland ecosystems (Moreno-de-las-Heras et al., 2019; Saco et al., 2020).

This work is grounded in conceptual background (Brunsden and Thornes, 1979; Thornes, 1985; Yair and Lavee, 1985; Lavee et al., 1998; Brunsden, 2001; Puigdefábregas, 2005), revisiting concepts related with the eco-geomorphic interplay at the hillslope scale. For that, we implemented some exploratory analytical methodologies in an attempt to provide insight into some issues by means of empirical evidence. We used recent technologies for acquiring very high quality topographic and image data (UAV and standard cartography), offering new analytical possibilities in a range of scales.

Specifically, in the first case study, we reviewed the current knowledge on structure and functional linkages across scales based on empirical evidence. This allowed identifying spatial heterogeneities (i.e. structure) relevant to the erosional response (i.e. function) from the patch-scale (Section 1.2). This is the scale from which the subsequent heterogeneities towards the higher scales emerge (Lavee et al., 1998; Puigdefábregas, 2005), and therefore, the variability is acting as a primary source of non-linearity governed by response thresholds (Calvo-Cases et al., 2003; Arnau-Rosalén et al., 2008). Consequently, we considered the patch-scale as the starting point of a multi-scale framework to unravel complex spatio-temporal interactions of hillslope

Table 1

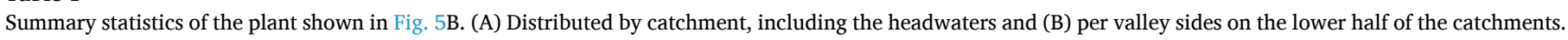

\begin{tabular}{|c|c|c|c|c|c|c|c|c|c|c|}
\hline & \multicolumn{3}{|c|}{ A. Catchment Number } & \multirow{2}{*}{-} & \multicolumn{6}{|c|}{ B. Hillslopes: Catchment Number_Aspect } \\
\hline & 1 & 2 & 3 & & 1_NE & 1_SW & 2_NE & 2_SW & 3_NE & 3_SW \\
\hline Number of plants & 38625 & 10215 & 130172 & & 5892 & 10683 & 1182 & 4989 & 11573 & 34639 \\
\hline Mean plant's area $\left(\mathrm{m}^{2}\right)$ & 0.65 & 1.40 & 0.50 & & 1.38 & 0.73 & 4.16 & 0.95 & 1.24 & 0.41 \\
\hline CV (\%) & 1025.64 & 3054.70 & 1027.69 & & 1044.06 & 878.76 & 2646.98 & 2530.34 & 1277.77 & 660.11 \\
\hline Percentile $75\left(\mathrm{~m}^{2}\right)$ & 0.38 & 0.50 & 0.38 & & 0.50 & 0.50 & 0.44 & 0.50 & 0.50 & 0.38 \\
\hline Percentile $95\left(\mathrm{~m}^{2}\right)$ & 1.81 & 2.69 & 1.50 & & 3.06 & 2.00 & 3.31 & 2.38 & 2.69 & 1.31 \\
\hline Vegetation Cover (\%) & 30.35 & 46.05 & 25.46 & & 44.00 & 31.37 & 63.59 & 37.78 & 43.07 & 22.09 \\
\hline
\end{tabular}


connectivity. This is in agreement with other frameworks dealing with ecosystem complexities (Peters et al., 2004, 2006). In addition, we considered that this approach opens a research pathway to deal with the current challenge of integrating structural and functional dimensions of hydrological connectivity (Wainwright et al., 2011; Baartman et al., 2013; Rodríguez-Caballero et al., 2014).

The Source-Sink Functional Composition triangles in Fig. 3, demonstrate a non-random data distribution. However, the identification of certain compositional domains related to differences in plant growth suggests that the abiotic fraction also contributes to some extent to the spatial heterogeneity, besides the widely recognised effect of vegetation (Pugnaire et al., 1996; Ludwig and Tongway, 2000; Puigdefábregas, 2005). The armouring-loop mechanistic described by Kirkby et al. (1998) and the underlying processes could be partially responsible for this spatial diversification. Accordingly, we propose as a working hypothesis, to extend the concept of VDSH (Puigdefábregas, 2005), with the additional effect of the abiotic SSCs contributing to enhance spatial heterogeneity. Also relevant as complementary evidence on the system functioning in drylands is the prevalence of surfaces with remarkable stoniness in the inter-canopy areas (Poesen and Lavee, 1994).

At the catchment scale, the results obtained from standard mapping sources (orthoimage and LiDAR) and $0.25 \mathrm{~m}-1 \mathrm{~m}$ spatial resolutions, seem satisfactory for an exploratory approach, and easy to apply to different areas.

Coupling studies related to the several scales that affect fluvial systems and the relevance of the geomorphological and ecological changes that can imply (Harvey, 2002), are rare. The hillslope-channel coupling studies have concentrated mainly in very active or erosive conditions, mainly where morphological changes are faster in relation to more linear upslope waves of aggression. However, as shown in this paper, the consequences of the coupling conditions can spread to the soil-plant system within the hillslopes.

The overlapping of anthropogenic and natural processes, especially in Mediterranean areas, introduces dispersion in the measurable variables of the landforms. However, we demonstrated that the consequences on some spatial differences in vegetation patterns, introduced by the coupling situations, are measurable. The difference in plant size distribution properties between coupled and decoupled hillslopes, in contrasted aspect, can be attributed to the fact that the erosive effectiveness of the diffuse waves of aggression was higher in the coupled conditions. The smaller plant size and the bigger size of the runoff source areas reveal that soil water storage is more limited in the coupled than in the decoupled hillslopes. This implies that the effect of coupling over plant size distribution can be similar to the differences in productivity introduced by climate, described by (Aguiar and Sala, 1999). The incision of the channels, affecting the base of the hillslopes, expands its influence upslope, limiting the soil thickness and the size of the plant mounds at the coupled hillslopes.

The increase of the timespan for morphological changes with the size of the studied landforms, as pointed out by Holling (1992) for the ecosystems, must always be taken into consideration in multi-scale approaches. While in a more detailed scale (i.e. patch) responses occur at the event timespan (e.g. runoff, or at the seasonal-scale; in properties like soil organic matter content (Boix-Fayos, 1999), at the coarser scale (i.e. hillslope or valley) the measurable changes have a longer operating timespan. In consequence, indirect measurements (i.e. plants size distribution) can be useful for the detection of differences in other system properties that require a more detailed resolution in order to be identified.

\section{Conclusions}

The working hypotheses presented here, based on a review of the academic literature and on empirical evidence, demonstrate that the system adapts to the geomorphological conditions, modifying the ecohydro-geomorphological interactions. Soil erosion processes affect vegetation development by distributing resources according to the availability of soil and the erosional potential. A complex system involving interactions and thresholds that can reverse the feedback loops is responsible for the soil and water redistribution on the hillslope.

At the patch scale, bare patches act as resources providers. When soil resources become limited, temporal changes in the erosive sequence reduce the provisioning rate. At this scale, the armouring state is an indicator of the system erosional conditions.

The stream channel incision modifies the hillslope form (i.e. basal convexity), and it is the starting point of an erosional sequence at the hillslopes. However, where a linear expansion of the aggression waves is limited by hillslope strength and filter resistance, the erosional process continues in a diffused way. The adaptation of the hillslopes to the coupled streams can be seen in the decrease of plant size and cover, indicating poorer soil resources.

Both spatial and time scales of the approach are relevant to be included in future work. At bare patches, the characteristics of the rock fragment cover are the main morphological property indicating the position in the time sequence and the state of availability of resources at the source patches. At the hillslope/valley scale, the degree of coupling of the hillslopes to the streams seems to be proportional to a degradation timescale.

\section{CRediT authorship contribution statement}

A. Calvo-Cases: Supervision, Methodology, Conceptualization, Writing - original draft, Writing - review \& editing, Formal analysis, Investigation, Resources, Visualization. E. Arnau-Rosalén: Conceptualization, Writing - original draft, Writing - review \& editing, Methodology, Formal analysis, Investigation, Resources, Visualization. C. BoixFayos: Writing - review \& editing, Supervision, Investigation, Resources. J. Estrany: Funding acquisition, Resources, Writing - review \& editing. M.J. Roxo: Resources, Writing - review \& editing. E. Symeonakis: Writing - review \& editing, Funding acquisition, Supervision, Resources.

\section{Declaration of competing interest}

The authors declare that they have no known competing financial interests or personal relationships that could have appeared to influence the work reported in this paper.

\section{Acknowledgements}

The authors are grateful to Prof. Juan Puigdefàbregas, whose legacy remains in multiple forms, particularly in the inspiration and gaze on the arid landscapes that he taught us. Adolfo Calvo-Cases and Joan Estrany acknowledge the financial support of the project MedHyCon-2 (CGL 2017-88200-R, PN I + D + I). Eva Arnau-Rosalén was supported by a European Commission Marie Sklodowska-Curie Fellowship (845146PantEOn- H2020-MSCA-IF-2018). Carolina Boix-Fayos acknowledges the financial support of the project DECADE20917/PI/18 (Seneca Foundation, Science Agency of the Murcia Region).

\section{References}

Abrahams, A.D., Parsons, A.J., Wainwright, J., 1995. Effects of vegetation change on interrill runoff and erosion, Walnut Gulch, southern Arizona. Geomorphology 13, $37-48$.

Aguiar, M.R., Sala, O.E., 1999. Patch structure, dynamics and implications for the functioning of arid ecosystems. Trends Ecol. Evol. 14, 273-277.

Alexander, R., Calvo, A., 1990. The influence of lichens on slope processes in some Spanish badlands. In: Thornes, J.B. (Ed.), Vegetation and Erosion. Wiley, Chichester, pp. 385-398.

Arnau-Rosalén, E., 2015. Patrones de distribución espacial y respuesta hidrológica de los componentes superficiales del suelo como control de la escorrentía superficial en condiciones ambientales mediterráneas. PhD University of Valencia, p. 268.

Arnau-Rosalén, E., Calvo-Cases, A., Boix-Fayos, C., Lavee, H., Sarah, P., 2008. Analysis of soil surface component patterns affecting runoff generation. An example of methods 
applied to Mediterranean hillslopes in Alicante (Spain). Geomorphology 101, 595-606.

Baartman, J.E.M., Masselink, R., Keesstra, S.D., Temme, A.J.A.M., 2013. Linking landscape morphological complexity and sediment connectivity. Earth Surf. Process. Landforms 38, 1457-1471.

Bautista, S., Mayor, Á.G., Bourakhouadar, J., Bellot, J., 2007. Plant spatial pattern predicts hillslope runoff and erosion in a semiarid mediterranean landscape. Ecosystems 10, 987-998.

Belnap, J., 2006. The potential roles of biological soil crusts in dryland hydrologic cycles. Hydrol. Process. 20, 3159-3178.

Belnap, J., Welter, J.R., Grimm, N.B., Barger, N., Ludwig, J.A., 2005. Linkages between microbial and hydrologic processes in arid and semiarid watersheds. Ecology 86, 298-307.

Bendig, J., Yu, K., Aasen, H., Bolten, A., Bennertz, S., Broscheit, J., Gnyp, M.L., Bareth, G., 2015. Combining UAV-based plant height from crop surface models, visible, and near infrared vegetation indices for biomass monitoring in barley. Int. J. Appl. Earth Obs. Geoinf. 39, 79-87.

Bergkamp, G., 1998. A hierarchical view of the interactions of runoff and infiltration with vegetation and microtopography in semiarid shrublands. Catena 33, 201-220.

Boer, M., Puigdefábregas, J., 2005. Effects of spatially structured vegetation patterns on hillslope erosion in a semiarid Mediterranean environment: a simulation study. Earth Surf. Process. Landforms 30, 149-167.

Boix-Fayos, C., 1999. Procesos geomórficos en diferentes condiciones ambientales mediterráneas: el estudio de la agregación y la hidrología de los suelos. PhD University of Valencia, p. 394.

Boix-Fayos, C., Calvo-Cases, A., Imeson, A., Soriano-Soto, M., 2001. Influence of soil properties on the aggregation of some Mediterranean soils and the use of aggregate size and stability as land degradation indicators. Catena 44, 47-67.

Boix-Fayos, C., Calvo-Cases, A., Imeson, A., Soriano-Soto, M., Tiemessen, I., 1998. Spatial and short-term temporal variations in runoff, soil aggregation and other soil properties along a mediterranean climatological gradient. Catena 33, 123-138.

Bracken, L.J., Croke, J., 2007. The concept of hydrological connectivity and its contribution to understanding runoff-dominated geomorphic systems. Hydrol. Process. 21, 1749-1763.

Bracken, L.J., Turnbull, L., Wainwright, J., Bogaart, P., 2015. Sediment connectivity: a framework for understanding sediment transfer at multiple scales. Earth Surf. Process. Landforms 40, 177-188.

Bracken, L.J., Wainwright, J., Ali, G.A., Tetzlaff, D., Smith, M.W., Reaney, S.M., Roy, A. G., 2013. Concepts of hydrological connectivity: research approaches, pathways and future agendas. Earth Sci. Rev. 119, 17-34.

Brandt, C.J., Thornes, J.B. (Eds.), 1996. Mediterranean Desertification and Land Use. Wiley, Chichester.

Brunsden, D., 2001. A critical assessment of the sensitivity concept in geomorphology. Catena 42, 99-123.

Brunsden, D., Thornes, J.B., 1979. Landscape sensitivity and change. Trans. Inst. Br. Geogr. 4, 463.

Caine, N., Swanson, F.J., 1989. Geomorphic coupling of hillslope and channel systems in two small mountain basins. Zeitschrift fur Geomorphologie 33, 189-203.

Calvo-Cases, A., Boix-Fayos, C., Imeson, A., 2003. Runoff generation, sediment movement and soil water behaviour on calcareous (limestone) slopes of some Mediterranean environments in southeast Spain. Geomorphology 50, 269-291.

Calvo-Cases, A., Harvey, A.M., Alexander, R.W., Cantón, Y., Lázaro, R., Solé-Benet, A., Puigdefábregas, J., 2014. Badlands in the tabernas basin, betic chain. In: Gutiérrez, F., Gutiérrez, M. (Eds.), Landscapes and Landforms of Spain. Springer, Dordrecht, pp. 197-211.

Cammeraat, E.L., 2004. Scale dependent thresholds in hydrological and erosion response of a semi-arid catchment in southeast Spain. Agric. Ecosyst. Environ. 104, 317-332.

Cavalli, M., Trevisani, S., Comiti, F., Marchi, L., 2013. Geomorphometric assessment of spatial sediment connectivity in small Alpine catchments. Geomorphology 188 $31-41$.

Chamizo, S., Cantón, Y., Rodríguez-Caballero, E., Domingo, F., 2016. Biocrusts positively affect the soil water balance in semiarid ecosystems. Ecohydrology 9, 1208-1221.

De Ploey, J., Poesen, J., 1984. Aggregate stability, runoff generation and interrill erosion. In: Geomorphology and Soils. Routledge, pp. 99-120.

Del Vecchio, J., DiBiase, R.A., Denn, A.R., Bierman, P.R., Caffee, M.W., Zimmerman, S.R., 2018. Record of coupled hillslope and channel response to Pleistocene erosion and deposition in a sandstone headwater valley, central Pennsylvania. GSA Bulletin 130 1903-1917.

Di Rienzo, J.A., Casanoves, F., Balzarini, M.G., Gonzalez, L., Tablada, M., Robledo, C.W. 2020. InfoStat versión 2020. Centro de Transferencia InfoStat. Facultad de Ciencias Agropecuarias, Universidad Nacional de Córdoba, Argentina. URL. http://www. infostat.com.ar.

Faulkner, H., 2008. Connectivity as a crucial determinant of badland morphology and evolution. Geomorphology 100, 91-103.

Faulkner, H., Alexander, R., Zukowskyj, P., 2008. Slope-channel coupling between pipes, gullies and tributary channels in the Mocatán catchment badlands, Southeast Spain. Earth Surf. Process. Landforms 33, 1242-1260.

García-Ruiz, J.M., Lana-Renault, N., Beguería, S., Lasanta, T., Regüés, D., NadalRomero, E., Serrano-Muela, P., López-Moreno, J.I., Alvera, B., Martí-Bono, C., Alatorre, L.C., 2010. From plot to regional scales: interactions of slope and catchment hydrological and geomorphic processes in the Spanish Pyrenees. Geomorphology 120, 248-257.

Geeson, N., Brandt, C.J., Thornes, J.B. (Eds.), 2001. Mediterranean Desertification: A Mosaic of Processes and Responses. Wiley, Chichester.

Gyssels, G., Poesen, J., Bochet, E., Li, Y., 2005. Impact of plant roots on the resistance of soils to erosion by water: a review. Prog. Phys. Geogr.: Earth Environ. 29, 189-217.
Harvey, A.M., 1978. Dissected alluvial fans in southeast Spain. Catena 5, 177-211.

Harvey, A.M., 2001. Coupling between hillslopes and channels in upland fluvial systems: implications for landscape sensitivity, illustrated from the Howgill Fells, northwest England. Catena 42, 225-250.

Harvey, A.M., 2002. Effective timescales of coupling within fluvial systems. Geomorphology 44, 175-201.

Harvey, A.M., 2012. The coupling status of alluvial fans and debris cones: a review and synthesis. Earth Surf. Process. Landforms 37, 64-76.

Harvey, A.M., Calvo-Cases, A., 1991. Process interactions and rill development on badland and gully slopes. Zeitschrift fur Geomorphogie Suppl. Bd 175-194.

Heckmann, T., Schwanghart, W., 2013. Geomorphic coupling and sediment connectivity in an alpine catchment - exploring sediment cascades using graph theory. Geomorphology 182, 89-103.

Holling, C.S., 1992. Cross-scale morphology, geometry, and dynamics of ecosystems. Ecol. Monogr. 62, 447-502.

Imeson, A.C., Prinsen, H., 2004. Vegetation patterns as biological indicators for identifying runoff and sediment source and sink areas for semi-arid landscapes in Spain. Agric. Ecosyst. Environ. 104, 333-342.

Katra, I., Lavee, H., Sarah, P., 2008. The effect of rock fragment size and position on topsoil moisture on arid and semi-arid hillslopes. Catena 72, 49-55.

Kéfi, S., Rietkerk, M., Alados, C.L., Pueyo, Y., Papanastasis, V.P., Elaich, A., Ruiter, P.C. de, 2007. Spatial vegetation patterns and imminent desertification in Mediterranean arid ecosystems. Nature 449, 213-217.

Kidron, G.J., Yair, A., 1997. Rainfall-runoff relationship over encrusted dune surfaces, Nizzana, Western Negev, Israel. Earth Surf. Process. Landforms 22, 1169-1184.

Kirkby, M.J., Abrahart, R., McMahon, M.D., Shao, J., Thornes, J.B., 1998. MEDALUS soil erosion models for global change. Geomorphology 24, 35-49.

Kirkby, M.J., Baird, A.J., Diamond, S.M., Lockwood, J.G., McMahon, M.G., Mitchell, P.L., Shao, J., Sheehy, J.E., Thornes, J.B., Woodward, F.I., 1996. The MEDALUS slope catena model: a physically based process model for hydrology, ecology and land degradation interactions. In: Brandt, C.J., Thornes, J.B. (Eds.), Mediterranean Desertification and Land Use. Wiley, Chichester, pp. 303-354.

Kutiel, P., Lavee, H., Ackermann, O., 1998. Spatial distribution of soil surface coverage on north and south facing hillslopes along a Mediterranean to extreme arid climatic gradient. Geomorphology 23, 245-256.

Lavee, H., Calvo-Cases, A., Sarah, P., Boix-Fayos, C., Ben-Shmuel, M., Arnau-Rosalén, E., 2004. Lessons and experience gained from 20 years of measuring soil erosion and related data in the Mediterranean: future challenges and the way ahead. In: van Asselen, S., Boix-Fayos, C., Imeson, A.C. (Eds.), Briefing Papers of the Second SCAPE Workshop in Cinque Terre. SCAPE, Amsterdam, pp. 23-36.

Lavee, H., Imeson, A.C., Sarah, P., 1998. The impact of climate change on geomorphology and desertification along a mediterranean-arid transect. Land Degrad. Dev. 9, 407-422.

Lavee, H., Poesen, J.W.A., 1991. Overland flow generation and continuity on stonecovered soil surfaces. Hydrol. Process. 5, 345-360.

Lavee, H., Yair, A., 1990. Spatial variability of overland flow in a small arid basin. Int. Assoc. Hydrol. Sci. Pub. 189, 105-120.

Lexartza-Artza, I., Wainwright, J., 2009. Hydrological connectivity: linking concepts with practical implications. Catena 79, 146-152.

Loheide, S.P., Booth, E.G., 2011. Effects of Changing Channel Morphology on Vegetation, Groundwater, and Soil Moisture Regimes in Groundwater-dependent Ecosystems.

Ludwig, J.A., Bastin, G.N., Chewings, V.H., Eager, R.W., Liedloff, A.C., 2007. Leakiness: a new index for monitoring the health of arid and semiarid landscapes using remotely sensed vegetation cover and elevation data. Ecol. Indicat. 7, 442-454.

Ludwig, J.A., Tongway, D.J., 2000. Viewing rangelands as landscape systems. In: Arnalds, O., Archer, S. (Eds.), Rangeland Desertification. Springer Netherlands, Dordrecht, pp. 39-52.

Ludwig, J.A., Wilcox, B.P., Breshears, D.D., Tongway, D.J., Imeson, A.C., 2005. Vegetation patches and runoff-erosion as interacting ecohydrological processes in semiarid landscapes. Ecology 86, 288-297.

Maestre, F.T., Eldridge, D.J., Soliveres, S., Kéfi, S., Delgado-Baquerizo, M., Bowker, M.A., García-Palacios, P., Gaitán, J., Gallardo, A., Lázaro, R., Berdugo, M., 2016. Structure and functioning of dryland ecosystems in a changing world. Annu. Rev. Ecol. Evol. Syst. 47, 215-237.

Maestre, F.T., Escolar, C., Guevara, M.L. de, Quero, J.L., Lázaro, R., DelgadoBaquerizo, M., Ochoa, V., Berdugo, M., Gozalo, B., Gallardo, A., 2013. Changes in biocrust cover drive carbon cycle responses to climate change in drylands. Global Change Biol. 19, 3835-3847.

Maestre, F.T., Escudero, A., 2009. Is the patch size distribution of vegetation a suitable indicator of desertification processes? Ecology 90, 1729-1735.

Mayor, A.G., Bautista, S., Rodriguez, F., Kéfi, S., 2019. Connectivity-mediated ecohydrological feedbacks and regime shifts in drylands. Ecosystems 22, 1497-1511.

Mayor, Á.G., Bautista, S., Small, E.E., Dixon, M., Bellot, J., 2008. Measurement of the connectivity of runoff source areas as determined by vegetation pattern and topography: a tool for assessing potential water and soil losses in drylands. Water Resour. Res, 44.

Michaelides, K., Hollings, R., Singer, M.B., Nichols, M.H., Nearing, M.A., 2018. Spatial and temporal analysis of hillslope-channel coupling and implications for the longitudinal profile in a dryland basin. Earth Surf. Process. Landforms 43 , 1608-1621.

Moreno-de-las-Heras, M., Lindenberger, F., Latron, J., Lana-Renault, N., Llorens, P., Arnáez, J., Romero-Díaz, A., Gallart, F., 2019. Hydro-geomorphological consequences of the abandonment of agricultural terraces in the Mediterranean region: key controlling factors and landscape stability patterns. Geomorphology 333, 73-91. 
Okin, G.S., Moreno-de-las-Heras, M., Saco, P.M., Throop, H.L., Vivoni, E.R., Parsons, A.J., Wainwright, J., Peters, D.P.C., 2015. Connectivity in dryland landscapes: shifting concepts of spatial interactions. Front. Ecol. Environ. 13, $20-27$.

Peters, D.P.C., Bestelmeyer, B.T., Herrick, J.E., Fredrickson, E.L., Monger, H.C., Havstad, K.M., 2006. Disentangling complex landscapes: new insights into arid and semiarid system dynamics. Bioscience 56, 491.

Peters, D.P.C., Pielke, R.A., Bestelmeyer, B.T., Allen, C.D., Munson-McGee, S., Havstad, K.M., 2004. Cross-scale interactions, nonlinearities, and forecasting catastrophic events. Proc. Natl. Acad. Sci. U.S.A. 101, 15130-15135.

Poesen, J., Lavee, H., 1994. Rock fragments in top soils: significance and processes. Catena 23, 1-28.

Poesen, J.W., Torri, D., Bunte, K., 1994. Effects of rock fragments on soil erosion by water at different spatial scales: a review. Catena 23, 141-166.

Pugnaire, F.I., Haase, P., Puigdefabregas, J., 1996. Facilitation between higher plant species in a semiarid environment. Ecology 77, 1420-1426.

Puigdefabregas, J., del Barrio, G., Boer, M.M., Gutiérrez, L., Solé, A., 1998. Differential responses of hillslope and channel elements to rainfall events in a semi-arid area. Geomorphology 23, 337-351.

Puigdefabregas, J., Sole, A., Gutierrez, L., del Barrio, G., Boer, M., 1999. Scales and processes of water and sediment redistribution in drylands: results from the Rambla Honda field site in Southeast Spain. Earth Sci. Rev. 48, 39-70.

Puigdefábregas, J., 2005. The role of vegetation patterns in structuring runoff and sediment fluxes in drylands. Earth Surf. Process. Landforms 30, 133-147.

Rivas-Martínez, S., 1987. Memoria del Mapa de Series de Vegetación de España. ICONA, Madrid.

Rodríguez-Caballero, E., Cantón, Y., Lazaro, R., Solé-Benet, A., 2014. Cross-scale interactions between surface components and rainfall properties. Non-linearities in the hydrological and erosive behavior of semiarid catchments. J. Hydrol. 517, 815-825.
Rodríguez-Iturbe, I., Porporato, A., 2004. Ecohydrology of Water-Controlled Ecosystems. Soil Moisture and Plant Dynamics. Cambridge University Press, Cambridge.

Roth, C.H., 2004. A framework relating soil surface condition to infiltration and sediment and nutrient mobilization in grazed rangelands of northeastern Queensland, Australia. Earth Surf. Process. Landforms 29, 1093-1104.

Saco, P.M., Rodríguez, J.F., Moreno-de las Heras, M., Keesstra, S., Azadi, S., Sandi, S., Baartman, J., Rodrigo-Comino, J., Rossi, M.J., 2020. Using hydrological connectivity to detect transitions and degradation thresholds: applications to dryland systems. Catena 186, 104354.

Sanchez, G., Puigdefabregas, J., 1994. Interactions of plant growth and sediment movement on slopes in a semi-arid environment. Geomorphology 9, 243-260.

Savi, S., Schneuwly-Bollschweiler, M., Bommer-Denns, B., Stoffel, M., Schlunegger, F., 2013. Geomorphic coupling between hillslopes and channels in the Swiss Alps. Earth Surf. Process. Landforms 38, 959-969.

Scanlon, T.M., Caylor, K.K., Levin, S.A., Rodriguez-Iturbe, I., 2007. Positive feedbacks promote power-law clustering of Kalahari vegetation. Nature 449, 209-212.

Schwinning, S., Sala, O.E., 2004. Hierarchy of responses to resource pulses in arid and semi-arid ecosystems. Oecologia 141, 211-220.

Thornes, J.B., 1985. The Ecology of Erosion. Geography 70, 222-235.

Thornes, J.B. (Ed.), 1990. Vegetation and Erosion: Processes and Environments. Wiley, Chichester.

Tongway, D., Hindley, N., 2004. Landscape function analysis: a system for monitoring rangeland function. Afr. J. Range Forage Sci. 21, 109-113.

Wainwright, J., Turnbull, L., Ibrahim, T.G., Lexartza-Artza, I., Thornton, S.F., Brazier, R. E., 2011. Linking environmental régimes, space and time: interpretations of structural and functional connectivity. Geomorphology 126, 387-404.

Yair, A., Lavee, H., 1976. Runoff generative process and runoff yield from arid talus mantled slopes. Earth Surf. Process. Landforms 1, 235-247.

Yair, A., Lavee, H., 1985. Runoff generation in arid and semi-arid zones. In: Anderson, M. G., Burt, T.P. (Eds.), Hydrological Forecasting. Wiley, Chichester, pp. 183-220. 